\title{
Use of Airborne Multi-Spectral IMAgery FOR WeEd DeteCtion IN FIELD CROPS
}

\author{
P. K. Goel, S. O. Prasher, R. M. Patel, D. L. Smith, A. DiTommaso
}

\begin{abstract}
In this article, the potential of multi-spectral airborne remote sensing is evaluated for the detection of weed infestation in corn (Zea mays L.) and soybean (Glycine max.) crops. A field plot experiment was laid out at the Lods Agronomy Research Center of Macdonald Campus, McGill University, Ste-Anne-de-Bellevue, Quebec, Canada. A multi-spectral image in 24 wavebands (475.12 $\mathrm{nm}$ to $910.01 \mathrm{~nm}$ wavelength range) was obtained using an airborne platform. Three weed treatments were selected to represent different weed conditions in corn and soybean, namely velvetleaf (Abutilon theophrasti Medic.), grasses, and mixed weeds. For the purpose of comparison, a treatment without weeds was also planted of each type of crop. Statistical analysis of radiance values recorded in different wavebands was performed to find the wavelength regions that were most useful for detecting different weed infestations. The results indicate that wavebands centered at 675.98 and $685.17 \mathrm{~nm}$ in the red region, and from $743.93 \mathrm{~nm}$ to $830.43 \mathrm{~nm}$ in the near-infrared, have good potential for distinguishing weeds in corn. For soybean, however, only one waveband $(811.40 \mathrm{~nm})$ was found to be useful. Efforts were also made to evaluate various ratios of radiance values recorded in red and near-infrared (NIR) wavebands for the detection of weeds. Much better results were obtained when ratios were used than with single wavebands. The results of this study will be helpful in selecting the most useful parts of the electromagnetic spectrum for the detection of weeds in corn and soybean fields.
\end{abstract}

Keywords. Airborne, Multi-spectral, Remote sensing, Corn, Soybean, Weeds.

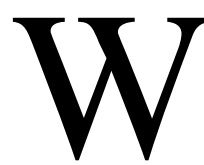

eed densities and species vary from field to field, and thus the uniform application of weed control measures over an entire field is neither economical nor environmentfriendly. However, such variations within fields have largely been ignored due to technological limitations in the application of herbicides (Medd and Pratley, 1998). In precision or site-specific crop and weed management, within-field weed variations are considered and patch spraying is used instead of the blanket application of herbicides. This reduces both treatment cost and herbicide loading in the environment (Christensen et al., 1998).

Precise weed detection is a prerequisite for both the formulation of a better weed management strategy and its timely implementation. Currently, technology to manage fields on the basis of sub-field units is available. However, for the commercial extension of site-specific herbicide application technology, rapid and cost-effective methods for creating accurate weed maps are required (Lamb et al., 1999). Presently, two different approaches for weed monitor-

Article was submitted for review in October 2000; approved for publication by the Information \& Electrical Technologies Division of ASAE in December 2001.

The authors are Pradeep K. Goel, ASAE Student Member, Graduate Student, Shiv O. Prasher, ASAE Member, Professor, and Ramanbhai M. Patel, Postdoctoral Fellow, Department of Agricultural and Biosystems Engineering; Donald L. Smith, Professor, and Antonio DiTommaso, former Assistant Professor, Department of Plant Science, McGill University, Macdonald Campus, Ste-Anne-de-Bellevue, Quebec. Corresponding author: Shiv O. Prasher, Department of Agricultural and Biosystems Engineering, McGill University, Macdonald Campus, 2111 Lakeshore Road, Ste-Anne-de-Bellevue, QC, Canada, H9X 3V9; phone: 514-398-7783; fax: 514-398-8387; email: shiv.prasher@mcgill.ca. ing and patch spraying are being followed. The first approach involves the development of weed maps and decision-making prior to the application of herbicides. The other approach is based on the real-time detection of weeds, and on decision-making at the time of spraying (Rew and Cousens, 1998). Ground surveying methods for mapping site-specific information about weeds are very time-consuming and labor-intensive. However, image-based remote sensing has potential applications in weed detection for site-specific weed management (Johnson et al., 1997; Moran et al., 1997; Lamb et al., 1999).

Remote sensing technology integrated with precision agriculture is the most promising application of the current technology in agriculture (Anderson et al., 1999). Due to better spatial and spectral resolutions of new satellites, both airborne platforms and satellites might be used to collect site-specific information. Currently, however, due to better resolution and flexibility in operation, airborne remote sensing is becoming increasingly important for time-specific and time-critical precision crop management (Moran et al., 1997). The potential of remote sensing has already been established in mapping crop areas and estimating crop yields over extensive areas. Current research efforts are directed toward assessing its utility for monitoring crop conditions and identifying specific factors detrimental to crop yield, including weed infestation. These applications could be easily integrated into precision agricultural practices.

The objective of this research was to demonstrate the potential of optical airborne remote sensing in the detection of some specific weeds, and general weedy conditions, in corn (Zea mays L.) and soybean (Glycine max. L.). The analysis of spectral and ground measurements was done to select wavebands (wavelength regions) suitable for distinguishing weed-infested and weed-free crop areas. 


\section{Remote Sensing for Weed Detection}

The spectral response of a crop or forest canopy depends mainly on the optical response of leaves and the underlying soil; however, other parts of the plants also influence the overall canopy response (Guyot, 1990). Zwiggelaar (1998) reviewed work on the potential use of spectral properties of plants for the discrimination of crops and weeds and reported that if the difference between the spectral responses in different wavebands of different plants can be measured, then weeds and crops can be discriminated. For the detection of weeds using remote sensing, it is required that a significant difference between the spectra of weeds and other factors (soil and plant) should exist, and the remote sensing instruments should have appropriate spatial and spectral resolution to measure this difference (Lamb, 1998).

Aerial photography in conventional color and in color-infrared has been used to detect weeds in agricultural and horticultural crops (Brown and Steckler, 1995). Curran (1985) reported on the use of high-resolution aerial photography for collecting information on crop disease, pest infestations, and the presence of weeds. Menges et al. (1985) showed that it is possible to distinguish weeds from crops in different weed-crop combinations using color-infrared photography. The maximum difference between weed populations and the crop was found to be in the near-infrared $(850 \mathrm{~nm})$ and visible $(550 \mathrm{~nm})$ wavelengths. Menges et al. identified climbing milkweed (Aarcostemma cyanchoides) in orange (Citrus ortensis) groves, ragweed (Parthenium hysterophorus) in carrot (Daucus carota) fields, johnsongrass (Sorghum halepense) and palmer amaranth (Amaranthus palmer) in cotton (Gossypium hirsutum), and london rocket (Sisymbrium irio) in cabbage (Brassicaoleracea). They suggested that the recognition of weeds in crops in this way could be attributed to differences in chlorophyll content, color, leaf area, and intercellular spaces in the individual leaves. These differences were not consistent and were dependent on the crop and on the weed-growth stage.

In another experiment, Brown et al. (1994) analyzed the spectral reflectance characteristics of the canopies of seven weed species by using a field radiometer and found four spectral bands (centered at 440,530,650, and above $730 \mathrm{~nm}$ wavelengths) that were useful in discriminating among the different weed species. Hanson et al. (1995) used colored images scanned from film and images from digital camera to develop maps of wild oat (Avena fatua $\mathrm{L}$.) infestations. They then used the information to guide the application of herbicides to the weed-infested areas only.

Several studies were conducted by Everitt et al. (1987, $1995,1996)$ using aerial photography and video imagery to distinguish among different weeds found in rangelands. They took photographs late in the season, when a particular weed had a distinct color due to foliage or flowers. Multi-spectral digital imagery was found to be useful for the detection of yellow starthistle (Centaurea solstitialis) and common St. John's wort (Hypericum perforatum) in rangelands (Lass et al., 1996). Lass and Callihan (1997) reported that the detection of two common rangeland perennial weeds, yellow hawkweed (Hieracium pratense) and ox-eye daisy (Chrysanthemum leucanthemum), was most accurate when plants were in full bloom, compared with early or post-bloom periods. The studies mentioned above indicate that the physiological stage or the time is also important for the detection of weeds.

Many vegetation indices (VIs) have been developed that combine reflectance at two or more wavelengths in different ways and that are useful in characterizing plant growth and development (Jackson and Huete, 1991). These VIs enhance the spectral contribution from green vegetation and minimize the contribution from soil and atmospheric factors. Hatfield and Pinter (1993) reviewed the applications of remote sensing in crop production, and highlighted the limitations of VIs in distinguishing weed populations from field crops. VIs are dependent on changes in plant biomass, leaf area, and the interception of radiation by the green portion of the canopy, but their application for discrimination between different plant species is limited. Hatfield and Pinter therefore concluded that the use of remote multi-spectral imagery for weed detection within crop canopies requires further research. Particularly, the relationships between remotely sensed data and weed infestation levels, weed species, and crop growth stages must be addressed. However, in a recent study, Zwiggelaar (1998) found some ratio vegetation indices (RVIs) and VIs useful for the discrimination of weeds from crops, particularly in row crops.

The studies mentioned above clearly indicate that remote sensing has good potential for the detection of weeds. In most of these studies, conventional color photography, digital photography, videography was used for the detection of weeds. The absence of quantitative data acquisition capabilities, the high cost, the limited availability of color-infrared (CIR) films, and the necessity for manual processing are limiting factors with these techniques. However, new multi-spectral airborne imaging systems are capable of providing data in digital format at much higher spatial and spectral resolutions in a cost-effective manner (Lamb, 1998). Therefore, this study was carried out to evaluate the potential of airborne multi-spectral remote sensing for the detection of different weed infestations in corn and soybean crops.

\section{Materials ANd Methods \\ Study Site and ExPERIMENT DetaILs}

This study was conducted at the Lods Agronomy Research Center, Macdonald Campus, McGill University, Ste-Annede-Bellevue, Quebec, in 1999. Corn and soybean, two important field crops in central Canada, were selected for the study. The effect of three different combinations of weeds in corn and soybean was studied separately. These combinations were: velvetleaf(Abutilon theophrasti), a mixture of different grasses (complete control of broadleaf weeds), and no weed control (mixture of all naturally occurring predominant weed types). Treatments of uninfested crops (full weed control) were also included in the study. Yellow foxtail (Setaria glauca) was the most prominent among the grassy weeds. Other grassy weeds were barnyard grass (Echinochloa crusgalli) and yellow nutsedge (Cyperus esculenthus). In the broadleaf weed category, velvetleaf (Abutilon theophrasti), redroot pigweed (Amaranthus retroflexus), and lamb's quarters (Chenopodium album) were the most prominent species.

On average, about 62 plants per $\mathrm{m}^{2}$ and 21 plants per $\mathrm{m}^{2}$ were present in the velvetleaf treatment of corn and soybean plots, respectively. In the grassy weed treatment, 48 yellow 
foxtail and 59 other grasses per $\mathrm{m}^{2}$ in corn plots and 23 yellow foxtail and 31 other grasses per $\mathrm{m}^{2}$ in soybean plots were present. As expected, a higher density of weeds was observed in plots with no weed control; about 53 yellow foxtail and an equal number of other grassy weeds and 19 broadleaf weeds per $\mathrm{m}^{2}$ were present in the corn plots. However, in the soybean plots, the density of weeds was considerably less. Only 54 grassy weeds and 6 broadleaf weeds per $\mathrm{m}^{2}$ were present in the soybean plots without any weed control. Hand weeding was done to remove weeds other than those selected for each treatment.

Thus, in total, four treatments (three weed combinations and one weed-free crop) were replicated three times and randomly allocated to twelve plots ( $3 \mathrm{~m} \times 3 \mathrm{~m}$ size) for corn and twelve plots for soybean. The corn and soybean were sown in the second week of May 1999 in a silty clay loam soil. Corn was sown at 76- $\mathrm{cm}$ row spacing at 70,000 seeds per ha, and soybean was sown at $18-\mathrm{cm}$ row spacing at 500,000 plants per ha. The fertilizer application rates were $115 \mathrm{~N}, 35 \mathrm{P}$, and $70 \mathrm{~K} \mathrm{~kg} / \mathrm{ha}$ in corn plots, and $40 \mathrm{P}$ and $40 \mathrm{~K}$ $\mathrm{kg} / \mathrm{ha}$ in soybean plots.

\section{Airborne Spectral Data Acquisition}

On 12 July 1999, a cloudless day, images of the study plots were acquired using an AISA airborne, pushbroom-type imaging spectrometer mounted on a Piper Seneca aircraft (Agrimage, Inc., Sherbrooke, Quebec). Corn and soybean were at late vegetative growth stages at the time of data acquisition. Tasseling in corn and pod formation in soybean started afterwards. Weeds were also at the vegetative growth stage. Flowering in weeds started much later. The data was acquired at a spatial resolution of $1 \mathrm{~m}$, in 24 wavebands in the visible to near-infrared range of the spectrum $(475.12 \mathrm{~nm}$ to $910.01 \mathrm{~nm}$ ). Details about the wavelength interval, central wavelength, width, and spectral regions of the different wavebands are given in table 1.

Radiometric corrections were done to convert the raw images, comprising digital number (DN) values, into radiance images. For this purpose, the raw DN values were converted to corrected DN values (radiance) according to the gain, offsets, DN dark current, and integration time. For the geometric processing of the collected data, an inertial unit recorded the movement of the plane during data acquisition. These values were then used to correct the image for roll, pitch, and yaw effects. A differential geographical positioning system (DGPS) unit was used for the georeferencing of the image. Agrimage, Inc., conducted both radiometric and geometric processing using their in-house software.

\section{Data Analysis}

Processed radiance images were then imported into the IDRISI GIS software (Version 2.00.000, Clark University, Worcester, Mass.) using PCI software (Version 6.2.1 (demo), PCI Geomatics, Richmond Hill, Ontario). Finally, representative values were acquired for each band by extracting the average radiance value from the central portion of the image of each plot. Statistical analysis was done in order to identify the optimal region of the electromagnetic spectrum useful for the detection of weeds. Scheffe's multiple-range test was used for the selection of the best spectral region for the discrimination of different weed infestations.
Table 1. Details of wavebands used in the study.

\begin{tabular}{ccccl}
\hline $\begin{array}{c}\text { Waveband } \\
\text { Number }\end{array}$ & $\begin{array}{c}\text { Wavelength } \\
\text { Interval } \\
(\mathrm{nm})\end{array}$ & $\begin{array}{c}\text { Band } \\
\text { Center } \\
(\mathrm{nm})\end{array}$ & $\begin{array}{c}\text { Width } \\
(\mathrm{nm})\end{array}$ & $\begin{array}{l}\text { Spectral } \\
\text { Region }\end{array}$ \\
\hline 1 & $475.12-479.86$ & 477.49 & 4.7 & Blue \\
2 & $500.40-508.30$ & 504.35 & 7.9 & Green \\
3 & $541.48-549.38$ & 545.43 & 7.9 & Green \\
4 & $552.40-560.75$ & 556.58 & 8.4 & Green \\
5 & $572.44-580.79$ & 576.62 & 8.3 & Green \\
6 & $587.47-595.82$ & 591.65 & 8.4 & Green \\
\hline 7 & $632.56-639.24$ & 635.90 & 6.7 & Red \\
8 & $672.64-679.32$ & 675.98 & 6.7 & Red \\
9 & $682.66-687.67$ & 685.17 & 5.0 & Red \\
10 & $687.67-692.68$ & 690.18 & 5.0 & Red \\
11 & $697.69-702.70$ & 700.20 & 5.0 & Red \\
12 & $702.70-707.71$ & 705.21 & 5.0 & Near-Infrared \\
\hline 13 & $714.52-719.71$ & 717.12 & 5.2 & Near-Infrared \\
14 & $724.90-730.09$ & 727.50 & 5.2 & Near-Infrared \\
15 & $733.55-738.74$ & 736.15 & 5.2 & Near-Infrared \\
16 & $743.93-749.12$ & 746.53 & 5.2 & Near-Infrared \\
17 & $754.31-759.50$ & 756.91 & 5.2 & Near-Infrared \\
18 & $775.07-778.53$ & 776.80 & 3.5 & Near-Infrared \\
\hline 19 & $794.10-797.56$ & 795.83 & 3.5 & Near-Infrared \\
20 & $809.67-813.13$ & 811.40 & 3.5 & Near-Infrared \\
21 & $826.97-830.43$ & 828.70 & 3.5 & Near-Infrared \\
22 & $854.65-859.84$ & 857.25 & 5.2 & Near-Infrared \\
23 & $878.87-884.06$ & 881.47 & 5.2 & Near-Infrared \\
24 & $904.82-910.01$ & 907.42 & 5.2 & Near-Infrared \\
\hline & & & &
\end{tabular}

\section{Results AND Discussion}

\section{SPECTRAL RESPONSE}

The spectral curves of the different weed infestation treatments are illustrated in figures 1 and 2 for corn and soybean, respectively. High absorption in the visible bands and high reflectance in the near-infrared bands are typical of vegetation reflectance curves. The radiance curves of all the treatments were similar in this regard. Guyot (1990) has reported that, in the visible domain (400 to $700 \mathrm{~nm}$ ), leaf reflectance is low (less then 15\%) due to high absorption by leaf pigments such as chlorophyll, xanthophyll, cartenoids, and anthocyanins. Since chlorophyll a and $\mathrm{b}$ in plant leaves exhibit maximum absorption in the blue and red bands, leaves have maximum reflectance at $550 \mathrm{~nm}$, in the yellow-green region. In the near-infrared region, reflectance of leaves alone could be as high as 50\%. However, the reflectance spectra of entire canopies are influenced by combinations of plants and the underlying soil. In all the treatments, the maximum radiance in the visible spectrum was recorded in wavebands centered at 545 and $556 \mathrm{~nm}$ (yellow-green region). Higher radiance was recorded in the near-infrared domain.

A comparison of the spectral responses of the different weed treatments indicated, on one hand, that corn and soybean crops, free from weeds, show the highest radiance in the red band as compared to all other treatments. On the other hand, minimum radiance values in the red bands occurred in the mixed-weed plots. A completely reversed trend was observed in the near-infrared region. The variation in radiance among different treatments could be attributed to the varying biomass (combined crop and weed) cover. 


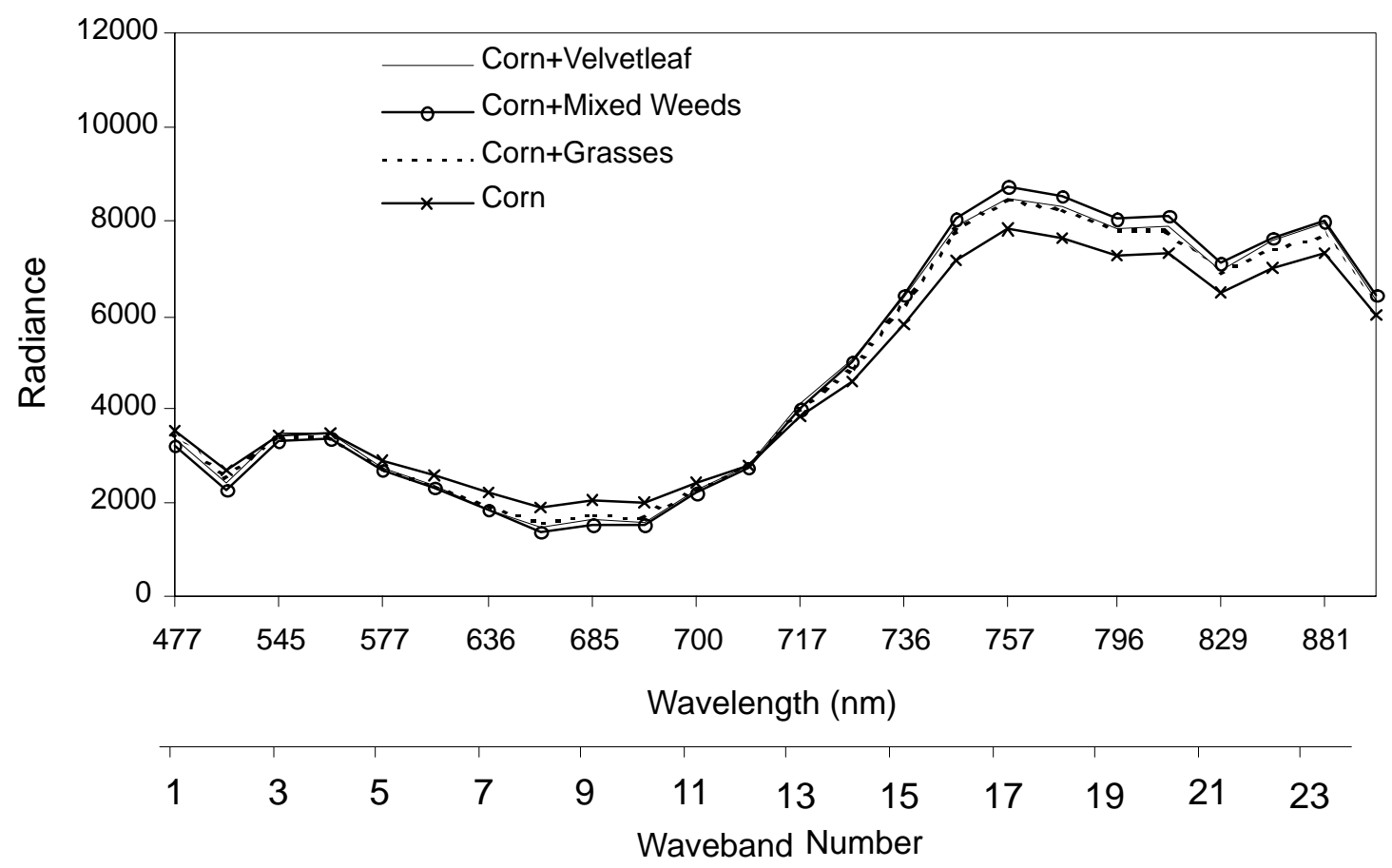

Figure 1. Mean radiance $\left(\mu \mathrm{W} / \mathrm{cm}^{2} / \mathrm{sr} / \mathrm{nm}\right)$ of corn under different weed treatments indifferent wavebands.

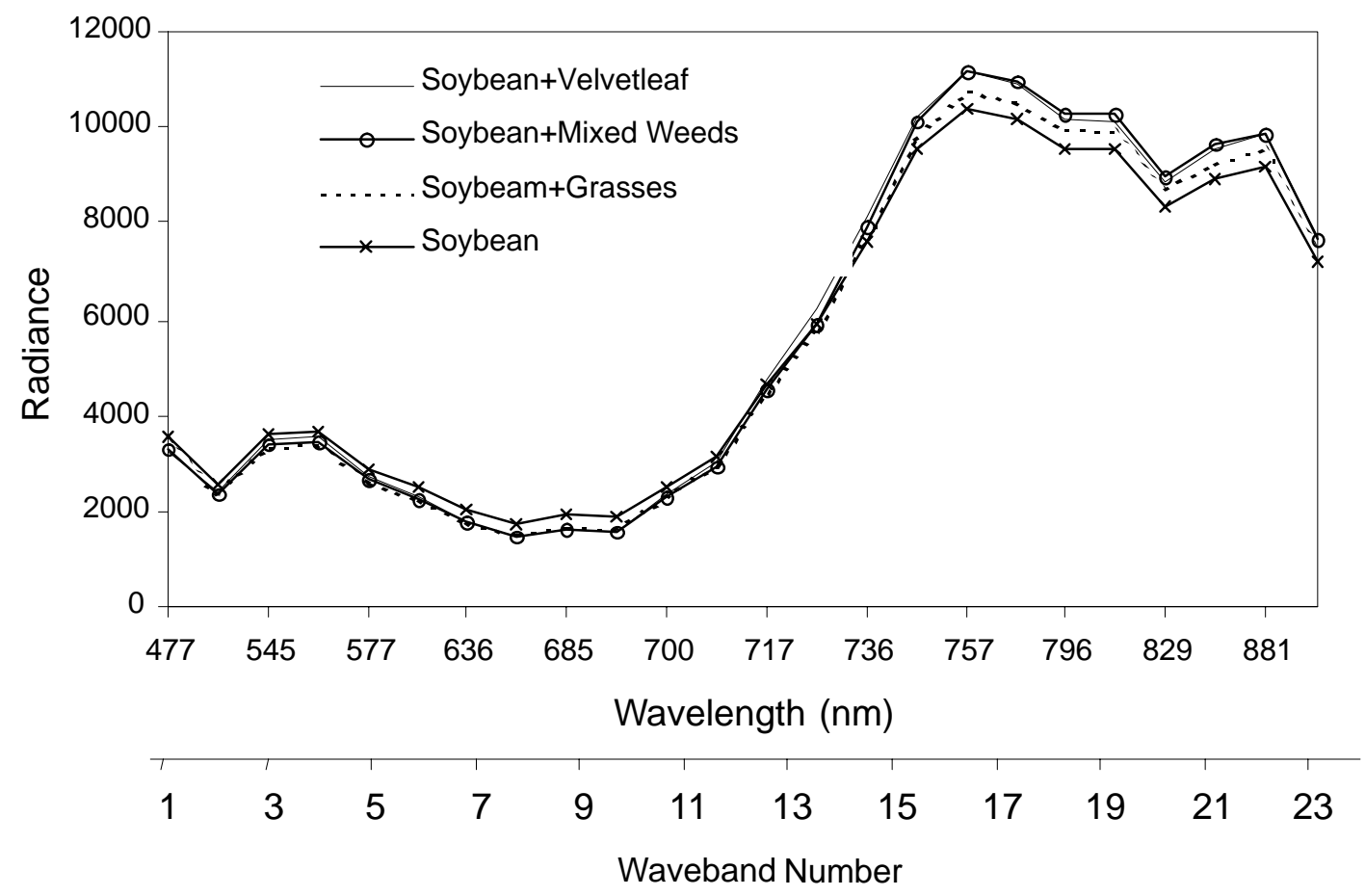

Figure 2. Mean radiance $\left(\mu \mathrm{W} / \mathrm{cm}^{2} / \mathrm{sr} / \mathrm{nm}\right)$ of soybean under different weed treatments in different wavebands.

Numerous research studies have reported good correlation between biomass and spectral data (Inoue et al., 2000; Cloutis et al. 1999). Average leaf area index (LAI) values, indicating both crop and weed ground cover, ranged from $1.73 \mathrm{~m}^{2} / \mathrm{m}^{2}$ (full weed control) to $3.11 \mathrm{~m}^{2} / \mathrm{m}^{2}$ (mixed weeds) and from $6.22 \mathrm{~m}^{2} / \mathrm{m}^{2}$ (full weed control) to $7.57 \mathrm{~m}^{2} / \mathrm{m}^{2}$ (velvetleaf treatment) for corn and soybean, respectively. However, the average LAI values were 2.31 and $2.11 \mathrm{~m}^{2} / \mathrm{m}^{2}$ for corn in velvetleaf and grassy weed treatments, respectively, while the LAI values in soybean treatments were 7.40 and
$7.27 \mathrm{~m}^{2} / \mathrm{m}^{2}$ in mixed-weed and grassy weed treatments, respectively. Greater differences in spectral response in the red and near-infrared wavebands clearly indicate the potential of these wavebands for discriminating weeds from crops. Waveband numbers 8, 9, and 10 in the red region and all bands from 16 onward in the near-infrared region seem to have good potential for detecting weeds. To confirm the potential utility of these bands, a statistical analysis was carried out, and the details of this analysis are discussed in the next section. 


\section{Statistical Analysis}

The spectral responses of the different treatments were statistically analyzed to test the distinguishability of different weed treatments. Scheffe's multiple-range test, which is considered to be more conservative than least-significant difference (LSD), was selected. SAS software (Version 6.11, SAS Institute, Inc., Cary, N.C.) was used to perform the analysis, which was carried out at the $95 \%$ significance level $(\mathrm{P}<0.05)$. The results of the analysis are summarized in tables 2 and 3 for corn and soybean, respectively, and they clearly identify the bands in the red and near-infrared wavelength regions potentially useful for the detection of weeds.

In the red region (wavebands 8 and 9), the radiance of a pure corn crop was significantly higher $(\mathrm{P}<0.05)$ than corn with mixed weeds. The radiance values for the remaining treatments (treatments with velvetleaf and only grasses) were between those of the above two treatments. However, they were not significantly different $(\mathrm{P}<0.05)$ from either corn or corn with mixed weeds. Thus, in band $8(675.98 \mathrm{~nm})$ and band $9(685.17 \mathrm{~nm})$ pure corn could be discriminated from corn with mixed weeds, but the presence of velvetleaf or grasses alone in corn could not be conclusively determined.

In the near-infrared region, bands 16 to 21 ( 746.53 to $828.70 \mathrm{~nm}$ ) seemed to show good potential for the discrimination of the different treatments. It was observed that in bands 16,17 , and 19 , the radiance of corn was significantly lower than $(\mathrm{P}<0.05)$ that of corn with velvetleaf and corn with mixed weeds. The radiance of corn with grasses, however, was not significantly different $(\mathrm{P}<0.05)$ from the

\begin{tabular}{|c|c|c|c|c|}
\hline \multirow{2}{*}{$\begin{array}{l}\text { Wave- } \\
\text { band } \\
\text { Number }\end{array}$} & \multicolumn{4}{|c|}{ Radiance $\left(\mu \mathrm{W} / \mathrm{cm}^{2} / \mathrm{sr} / \mathrm{nm}\right)$} \\
\hline & $\begin{array}{c}\text { Corn + } \\
\text { Velvetleaf }\end{array}$ & $\begin{array}{c}\text { Corn }+ \\
\text { Mixed weeds }\end{array}$ & $\begin{array}{l}\text { Corn }+ \\
\text { Grasses }\end{array}$ & $\begin{array}{c}\text { Corn }+ \\
\text { No weeds }\end{array}$ \\
\hline 1 & $3379 \pm 140^{\mathrm{a}}$ & $3206 \pm 107$ a & $3492 \pm 64^{a}$ & $3566 \pm 131^{a}$ \\
\hline 2 & $2454 \pm 97^{\mathrm{a}}$ & $2271 \pm 53^{\text {a }}$ & $2515 \pm 80^{\mathrm{a}}$ & $2705 \pm 162^{a}$ \\
\hline 3 & $3473 \pm 18$ a & $3323 \pm 138^{\text {a }}$ & $3449 \pm 93$ a & $3459 \pm 148^{\text {a }}$ \\
\hline 4 & $3513 \pm 11^{a}$ & $3359 \pm 142^{\text {a }}$ & $3454 \pm 100^{\text {a }}$ & $3485 \pm 159$ a \\
\hline 5 & $2773 \pm 9^{a}$ & $2676 \pm 122$ a & $2774 \pm 85^{a}$ & $2891 \pm 158^{\text {a }}$ \\
\hline 6 & $2382 \pm 21^{\mathrm{a}}$ & $2315 \pm 101$ a & $2392 \pm 87^{a}$ & $2576 \pm 167^{\mathrm{a}}$ \\
\hline 7 & $1871 \pm 48^{a}$ & $1826 \pm 78^{a}$ & $1946 \pm 72^{a}$ & $2205 \pm 150^{a}$ \\
\hline 8 & $1484 \pm 57 \mathrm{ab}$ & $1389 \pm 41^{b}$ & $1595 \pm 72^{a b}$ & $1898 \pm 170^{a}$ \\
\hline 9 & $1637 \pm 70 \mathrm{ab}$ & $1526 \pm 49^{b}$ & $1762 \pm 88 \mathrm{ab}$ & $2073 \pm 184$ a \\
\hline 10 & $1604 \pm 73^{a}$ & $1527 \pm 52^{a}$ & $1714 \pm 83^{a}$ & $1988 \pm 165^{\mathrm{a}}$ \\
\hline 11 & $2273 \pm 62^{a}$ & $2225 \pm 112^{\text {a }}$ & $2290 \pm 101^{a}$ & $2437 \pm 150^{a}$ \\
\hline 12 & $2824 \pm 81^{a}$ & $2743 \pm 162^{\text {a }}$ & $2778 \pm 119^{\text {a }}$ & $2823 \pm 150^{a}$ \\
\hline 13 & $4104 \pm 84^{a}$ & $4012 \pm 232^{\text {a }}$ & $3941 \pm 163^{a}$ & $3863 \pm 143^{a}$ \\
\hline 14 & $5062 \pm 60^{\mathrm{a}}$ & $5020 \pm 244^{\text {a }}$ & $4848 \pm 127^{\text {a }}$ & $4608 \pm 105^{\mathrm{a}}$ \\
\hline 15 & $6392 \pm 28$ a & $6428 \pm 246^{\text {a }}$ & $6241 \pm 72^{a}$ & $5831 \pm 82^{a}$ \\
\hline 16 & $7858 \pm 43^{a}$ & $8017 \pm 219^{\text {a }}$ & $7781 \pm 54 \mathrm{ab}$ & $7198 \pm 85^{b}$ \\
\hline 17 & $8484 \pm 61^{a}$ & $8714 \pm 204$ a & $8432 \pm 76^{a b}$ & $7824 \pm 101 \mathrm{~b}$ \\
\hline 18 & $8295 \pm 72^{a}$ & $8533 \pm 187^{a}$ & $8246 \pm 59^{a}$ & $7662 \pm 77^{b}$ \\
\hline 19 & $7846 \pm 110^{a}$ & $8053 \pm 187$ a & $7818 \pm 8$ ab & $7282 \pm 58^{b}$ \\
\hline 20 & $7899 \pm 135^{a b}$ & $8092 \pm 189^{\text {a }}$ & $7842 \pm 30^{a b}$ & $7339 \pm 37^{b}$ \\
\hline 21 & $6994 \pm 159$ ab & $7146 \pm 180^{a}$ & $6945 \pm 14$ ab & $6498 \pm 36^{b}$ \\
\hline 22 & $7621 \pm 178^{a}$ & $7689 \pm 245$ a & $7439 \pm 49^{a}$ & $7022 \pm 75^{a}$ \\
\hline 23 & $7916 \pm 227^{\text {a }}$ & $8001 \pm 287^{\text {a }}$ & $7714 \pm 50^{a}$ & $7344 \pm 137$ a \\
\hline 24 & $6334 \pm 230^{\mathrm{a}}$ & $6444 \pm 231^{a}$ & $6233 \pm 64^{a}$ & $6038 \pm 180^{a}$ \\
\hline
\end{tabular}

Mean radiance values ( \pm SE) with same superscript letters in each band are not significantly different (Scheffe's multiple-range test, $\mathrm{P}<0.05$ ).
Table 3. Results of the statistical analysis on radiance in different wavebands for soybean.

\begin{tabular}{|c|c|c|c|c|}
\hline \multirow{2}{*}{$\begin{array}{l}\text { Wave- } \\
\text { band } \\
\text { Number }\end{array}$} & \multicolumn{4}{|c|}{ Radiance $\left(\mu \mathrm{W} / \mathrm{cm}^{2} / \mathrm{sr} / \mathrm{nm}\right)$} \\
\hline & $\begin{array}{l}\text { Soybean }+ \\
\text { Velvetleaf }\end{array}$ & $\begin{array}{c}\text { Soybean }+ \\
\text { Mixed weeds }\end{array}$ & $\begin{array}{l}\text { Soybean + } \\
\text { Grasses }\end{array}$ & $\begin{array}{l}\text { Soybean }+ \\
\text { No weeds }\end{array}$ \\
\hline 1 & $3266 \pm 39^{a}$ & $3277 \pm 40^{\mathrm{a}}$ & $3534 \pm 85^{a}$ & $3576 \pm 156^{\mathrm{a}}$ \\
\hline 2 & $2386 \pm 6^{\mathrm{a}}$ & $2375 \pm 73^{a}$ & $2370 \pm 74^{\mathrm{a}}$ & $2589 \pm 83^{\text {a }}$ \\
\hline 3 & $3534 \pm 114^{\mathrm{a}}$ & $3408 \pm 121^{a}$ & $3355 \pm 79$ a & $3600 \pm 52^{\mathrm{a}}$ \\
\hline 4 & $3566 \pm 131^{\mathrm{a}}$ & $3458 \pm 128^{a}$ & $3384 \pm 81^{\mathrm{a}}$ & $3648 \pm 59^{\mathrm{a}}$ \\
\hline 5 & $2744 \pm 73^{\text {a }}$ & $2666 \pm 107^{\text {a }}$ & $2616 \pm 74^{\mathrm{a}}$ & $2888 \pm 55^{\mathrm{a}}$ \\
\hline 6 & $2314 \pm 44^{\text {a }}$ & $2260 \pm 100^{a}$ & $2248 \pm 83^{a}$ & $2498 \pm 58$ a \\
\hline 7 & $1800 \pm 20^{a}$ & $1786 \pm 85^{a}$ & $1801 \pm 65^{a}$ & $2041 \pm 66^{\mathrm{a}}$ \\
\hline 8 & $1464 \pm 35^{\mathrm{a}}$ & $1464 \pm 74^{\mathrm{a}}$ & $1512 \pm 89^{a}$ & $1737 \pm 82^{a}$ \\
\hline 9 & $1618 \pm 33^{a}$ & $1614 \pm 81^{a}$ & $1671 \pm 94^{\text {a }}$ & $1917 \pm 92^{\mathrm{a}}$ \\
\hline 10 & $1595 \pm 29^{\mathrm{a}}$ & $1596 \pm 80^{\mathrm{a}}$ & $1646 \pm 81^{\mathrm{a}}$ & $1861 \pm 91^{\mathrm{a}}$ \\
\hline 11 & $2372 \pm 57$ a & $2312 \pm 101^{a}$ & $2308 \pm 80^{\mathrm{a}}$ & $2528 \pm 62^{\text {a }}$ \\
\hline 12 & $3057 \pm 94^{\mathrm{a}}$ & $2945 \pm 108^{a}$ & $2930 \pm 96^{\text {a }}$ & $3137 \pm 62^{\text {a }}$ \\
\hline 13 & $4778 \pm 170^{a}$ & $4542 \pm 122^{a}$ & $4443 \pm 117^{a}$ & $4679 \pm 44^{\mathrm{a}}$ \\
\hline 14 & $6204 \pm 218^{a}$ & $5937 \pm 80^{a}$ & $5744 \pm 116^{\mathrm{a}}$ & $5917 \pm 34^{\mathrm{a}}$ \\
\hline 15 & $8112 \pm 237^{\text {a }}$ & $7899 \pm 41^{\mathrm{a}}$ & $7630 \pm 150^{\mathrm{a}}$ & $7607 \pm 46^{\text {a }}$ \\
\hline 16 & $10229 \pm 251^{\mathrm{a}}$ & $10113 \pm 73^{a}$ & $9722 \pm 223^{\text {a }}$ & $9528 \pm 67$ a \\
\hline 17 & $11173 \pm 235^{\mathrm{a}}$ & $11139 \pm 108^{\mathrm{a}}$ & $10743 \pm 280^{\mathrm{a}}$ & $10391 \pm 122^{a}$ \\
\hline 18 & $10879 \pm 187^{a}$ & $10952 \pm 151^{a}$ & $10557 \pm 263^{a}$ & $10148 \pm 119^{a}$ \\
\hline 19 & $10168 \pm 152^{a}$ & $10262 \pm 103^{a}$ & $9934 \pm 236^{\mathrm{a}}$ & $9512 \pm 148^{\text {a }}$ \\
\hline 20 & $10137 \pm 135 \mathrm{ab}$ & $10248 \pm 84^{a}$ & $9924 \pm 193 \mathrm{ab}$ & $9514 \pm 155^{b}$ \\
\hline 21 & $8857 \pm 135^{\mathrm{a}}$ & $8979 \pm 118^{\text {a }}$ & $8712 \pm 173$ a & $8326 \pm 117$ a \\
\hline 22 & $9517 \pm 187^{\text {a }}$ & $9617 \pm 138^{\mathrm{a}}$ & $9248 \pm 170^{\text {a }}$ & $8929 \pm 160^{\text {a }}$ \\
\hline 23 & $9826 \pm 176^{\mathrm{a}}$ & $9860 \pm 138^{\text {a }}$ & $9552 \pm 108^{a}$ & $9189 \pm 162^{\mathrm{a}}$ \\
\hline 24 & $7692 \pm 132 \mathrm{a}$ & $7654 \pm 125^{a}$ & $7426 \pm 69^{\text {a }}$ & $7194 \pm 163$ a \\
\hline
\end{tabular}

Mean radiance values $( \pm$ SE) with same superscript letters in each band are not significantly different (Scheffe's multiple-range test, $\mathrm{P}<0.05$ ).

radiance of the other treatments. In band $18(776.80 \mathrm{~nm})$, the radiance of the clean crop was significantly lower $(\mathrm{P}<0.05)$ than that of corn infested with any of the weeds.

The statistical analysis performed for the soybean crop showed that, with the exception of band $20(811.40 \mathrm{~nm})$, the recorded radiance values were not significantly different $(\mathrm{P}<$ $0.05)$ for the weed-infested and weed-free soybean treatments. In band 20, however, radiance values were statistically different for weed-free and mixed-weed treatments. Even in this band, radiance in treatments of soybean with velvetleaf and soybean with grasses were still not statistically different from the weed-free or mixed-weed soybean treatments.

At the time of observation, weeds were at the vegetative growth stage. Generally it is more difficult to detect weeds at this stage. Researchers have reported that weed detection is easier at the flowering stage (Lass and Callihan, 1997). Weed detection must be done early in the growing season so that weeds can be eliminated quickly and effectively without causing any serious damage to the main crop. However, some studies also suggest that weed aggregations at a specific location over time are stable (Cardina et al., 1995; Johnson et al., 1996); in such situations, weed mapping could be useful in site-specific weed management for the following year as well. The detection of weeds at later stages is also important because adopting appropriate measures at this stage for stopping seed production and reproduction could control further propagation and the spreading of weeds in the next year and into newer fields. 
Research studies cited at the beginning of this article indicate that a number of band ratios and vegetation indices based on radiance in different wavelength regions have been developed to discriminate between different types of vegetation. These VIs usually involve combinations of two or more bands in the red and infrared regions. Therefore, attempts were also made to evaluate the utility of different band ratios for discriminating between the different weed treatments. The most promising bands for this purpose in the red (8 and 9) and infrared regions (16 to 21) were investigated. Different band ratios (red/infrared) for all possible combinations of selected red and infrared regions were calculated, and a similar statistical analysis was carried out to test the separability of different treatments. The separability of the two treatments is based on the difference in two treatment means, considering the various error terms. It ultimately represents the difference of two treatment means. The results of this analysis are presented in tables 4 and 5.

Results for corn clearly establish that the values of these band ratios for pure corn were significantly different $(\mathrm{P}<$ 0.05 ) from those of weed-infested corn. However, corn with velvetleaf showed no statistically significant differences

Table 4. Results of the statistical analysis on radiance ratios in different wavebands for corn.

\begin{tabular}{|c|c|c|c|c|}
\hline \multirow{2}{*}{$\begin{array}{l}\text { Wave- } \\
\text { band } \\
\text { Number }\end{array}$} & \multicolumn{4}{|c|}{ Radiance Ratio $\left(\times 10^{-3}\right)$} \\
\hline & $\begin{array}{c}\text { Corn }+ \\
\text { Velvetleaf }\end{array}$ & $\begin{array}{c}\text { Corn }+ \\
\text { Mixed weeds }\end{array}$ & $\begin{array}{l}\text { Corn + } \\
\text { Grasses }\end{array}$ & $\begin{array}{c}\text { Corn }+ \\
\text { No weeds }\end{array}$ \\
\hline $8 / 16$ & $189 \pm 7^{b}$ & $173 \pm 4^{b}$ & $205 \pm 9$ ab & $264 \pm 25^{\mathrm{a}}$ \\
\hline $8 / 17$ & $175 \pm 7^{b}$ & $159 \pm 3^{b}$ & $189 \pm 9$ ab & $243 \pm 23^{a}$ \\
\hline $8 / 18$ & $179 \pm 6^{b}$ & $163 \pm 4 b$ & $194 \pm 9 a b$ & $248 \pm 24^{a}$ \\
\hline $8 / 19$ & $189 \pm 5 b$ & $173 \pm 5 b$ & $204 \pm 9$ ab & $261 \pm 25^{\mathrm{a}}$ \\
\hline $8 / 20$ & $188 \pm 4^{b}$ & $172 \pm 5^{b}$ & $203 \pm 9$ ab & $259 \pm 24^{a}$ \\
\hline $8 / 21$ & $212 \pm 3^{b}$ & $195 \pm 6^{b}$ & $230 \pm 11 \mathrm{ab}$ & $292 \pm 28^{a}$ \\
\hline $9 / 16$ & $208 \pm 9^{b}$ & $190 \pm 4^{b}$ & $227 \pm 11$ ab & $289 \pm 27^{a}$ \\
\hline $9 / 17$ & $193 \pm 8^{b}$ & $175 \pm 4^{b}$ & $209 \pm 10^{a b}$ & $265 \pm 25^{\mathrm{a}}$ \\
\hline $9 / 18$ & $197 \pm 7 b$ & $179 \pm 5^{b}$ & $214 \pm 11^{a b}$ & $271 \pm 26^{a}$ \\
\hline $9 / 19$ & $209 \pm 6^{b}$ & $190 \pm 6^{b}$ & $225 \pm 11^{a b}$ & $285 \pm 27^{a}$ \\
\hline $9 / 20$ & $207 \pm 5^{b}$ & $189 \pm 6^{b}$ & $225 \pm 11^{a b}$ & $283 \pm 26^{a}$ \\
\hline $9 / 21$ & $234 \pm 5 b$ & $214 \pm 6^{b}$ & $254 \pm 13^{a b}$ & $319 \pm 30^{\mathrm{a}}$ \\
\hline
\end{tabular}

Mean radiance ratio values ( \pm SE) with same superscript letters in each band are not significantly different (Scheffe's multiple-range test, $\mathrm{P}<0.05$ ).

Table 5. Results of the statistical analysis on radiance ratios in different bands for soybean.

\begin{tabular}{ccccc}
\hline \multirow{2}{*}{$\begin{array}{c}\text { Wave- } \\
\text { band } \\
\text { Number }\end{array}$} & $\begin{array}{c}\text { Soybean }+ \\
\text { Velvetleaf }\end{array}$ & $\begin{array}{c}\text { Soybean }+ \\
\text { Mixed weeds }\end{array}$ & $\begin{array}{c}\text { Soybean }+ \\
\text { Grasses }\end{array}$ & $\begin{array}{c}\text { Soybean }+ \\
\text { No weeds }\end{array}$ \\
\hline $8 / 16$ & $143 \pm 7^{\mathrm{a}}$ & $145 \pm 8^{\mathrm{a}}$ & $155 \pm 8^{\mathrm{a}}$ & $182 \pm 8^{\mathrm{a}}$ \\
$8 / 17$ & $131 \pm 6^{\mathrm{b}}$ & $132 \pm 8^{\mathrm{ab}}$ & $141 \pm 8^{\mathrm{ab}}$ & $167 \pm 7^{\mathrm{a}}$ \\
$8 / 18$ & $135 \pm 6^{\mathrm{ab}}$ & $134 \pm 9^{\mathrm{b}}$ & $143 \pm 8^{\mathrm{ab}}$ & $171 \pm 7^{\mathrm{a}}$ \\
$8 / 19$ & $144 \pm 6^{\mathrm{b}}$ & $143 \pm 9^{\mathrm{b}}$ & $152 \pm 8^{\mathrm{ab}}$ & $183 \pm 7^{\mathrm{a}}$ \\
$8 / 20$ & $145 \pm 5^{\mathrm{b}}$ & $143 \pm 8^{\mathrm{b}}$ & $152 \pm 8^{\mathrm{ab}}$ & $182 \pm 7^{\mathrm{a}}$ \\
$8 / 21$ & $165 \pm 7^{\mathrm{ab}}$ & $163 \pm 10^{\mathrm{b}}$ & $173 \pm 9^{\mathrm{ab}}$ & $209 \pm 8^{\mathrm{a}}$ \\
\hline $9 / 16$ & $158 \pm 7^{\mathrm{a}}$ & $160 \pm 9^{\mathrm{a}}$ & $172 \pm 9^{\mathrm{a}}$ & $201 \pm 9^{\mathrm{a}}$ \\
$9 / 17$ & $145 \pm 6^{\mathrm{b}}$ & $145 \pm 9^{\mathrm{b}}$ & $156 \pm 9^{\mathrm{ab}}$ & $184 \pm 8^{\mathrm{a}}$ \\
$9 / 18$ & $149 \pm 6^{\mathrm{b}}$ & $148 \pm 9^{\mathrm{b}}$ & $158 \pm 9^{\mathrm{ab}}$ & $189 \pm 8^{\mathrm{a}}$ \\
$9 / 19$ & $159 \pm 6^{\mathrm{b}}$ & $157 \pm 10^{\mathrm{b}}$ & $168 \pm 9^{\mathrm{ab}}$ & $201 \pm 8^{\mathrm{a}}$ \\
$9 / 20$ & $160 \pm 5^{\mathrm{b}}$ & $158 \pm 9^{\mathrm{b}}$ & $168 \pm 9^{\mathrm{ab}}$ & $201 \pm 8^{\mathrm{a}}$ \\
$9 / 21$ & $183 \pm 7^{\mathrm{b}}$ & $180 \pm 11^{\mathrm{b}}$ & $192 \pm 10^{\mathrm{ab}}$ & $230 \pm 9^{\mathrm{a}}$ \\
\hline
\end{tabular}

Mean radiance ratio values ( \pm SE) with same superscript letters in each band are not significantly different (Scheffe's multiple-range test, $\mathrm{P}<0.05$ ). from the mixed-weed or grassy weed treatments. Thus, the band ratios, given in table 4 and band 18 , can be used to determine the presence of weeds in corn fields.

The statistical analysis carried out using band ratios for discriminating different weed infestation treatments in soybean (table 5) illustrates that better separability among different weed treatments could be obtained if band ratios are used. However, a similar difficulty was observed in distinguishing velvetleaf and grasses treatments. It was observed that, in most of the band ratios tried, a weed-free soybean crop and soybeans with mixed weeds were distinguishable, but it was not possible to differentiate other weed treatments. In the case of the soybean treatments, it was even difficult to make a distinction between the different weed treatments visually, because the dominant canopy coverage of the soybean crop suppressed weed growth in the velvetleaf and grassy weed treatments.

\section{Conclusions}

In this article, results are presented from a field study carried out to explore the potential of multi-spectral airborne remote sensing in detecting weed infestations in corn and soybean crops. Statistical analysis indicated that the spectral bands centered at 675.98 and $685.17 \mathrm{~nm}$ (waveband 8 and 9) in the red region and near-infrared bands from 743.93 to $830.43 \mathrm{~nm}$ (wavebands 16 to 21 ) have good potential for discriminating between weed-free and weed-infested areas in corn. However, waveband $18(776.80 \mathrm{~nm})$ was found to be the best of all the bands for clearly distinguishing weed-infested areas in corn. In the case of soybean, only waveband $20(811.40 \mathrm{~nm})$ was useful for distinguishing mixed-weed and weed-free treatments. However, it was observed that other weed treatments (velvetleaf and grasses) were not distinguishable from either the mixed-weed or weed-free treatments. When ratios of red and infrared bands were used, better results were obtained for the distinction between weed-free and various weed-infested treatments. Thus, the study clearly indicates the potential of multi-spectral airborne imagery for the detection of weed infestation in corn and soybean. Although there were differences between the radiance values for some weed infestation types, it was difficult to clearly distinguish between other treatments. More field experiments, at better spectral and spatial resolution, are needed to confirm and improve upon these results.

\section{REFERENCES}

Anderson, J. E., R. I. Fischer, and S. R. Deloach. 1999. Remote sensing and precision agriculture: Ready for harvest or still maturing. Photogrammetric Eng. and Remote Sensing 65(10): 1118-1123.

Brown, R. B., and J. P. G. A. Steckler. 1995. Prescription maps for spatially variable herbicide application in no-till corn. Trans. ASAE 38(3): 659-666.

Brown, R. B., J. P. G. A. Steckler, and W. G. Anderson. 1994. Remote sensing for identification of weeds in no-till corn. Trans. ASAE 37(1): 297-302.

Cardina, J., D. H. Sparrow, and E. L. McCoy. 1995. Analysis of spatial distribution of common lamb's quarters (Chenopodium album) in no-till soybean (Glycine max.). Weed Science 43(2): 258-268. 
Christensen, S., E. Nordbo, T. Heisel, and A. M. Walter. 1998. Overview of development in precision weed management: Issues of interest and future directions being considered in Europe. In Precision Weed Management in Crops and Pasture: Proceedings of a Workshop, 3-13. R. W. Medd and J. E. Pratley, eds. 5-6 May. Adelaide, South Australia: CRC for Weed Management Systems.

Cloutis, E. A., D. R. Connery, and F. J. Dover. 1999. Agricultural crop monitoring using airborne multi-spectral imagery and $\mathrm{C}-$ band synthetic aperture radar. International J. Remote Sensing 20(4): 767-787.

Curran, P. J. 1985. Aerial photography for the assessment of crop condition: A review. Applied Geography 5(4): 347-360.

Everitt, J. H., R. D. Pettit, and M. A. Alaniz. 1987. Remote sensing of broom snake weed (Gutierrezia sarothrae) and spiny aster (Aster spinosus). Weed Science 35(2): 295-302.

Everitt, J. H., G. L. Anderson, D. E. Escobar, M. R. Davis, N. R. Spencer, and R. J. Andrascik. 1995. Use of remote sensing for detecting and mapping leafy spurge (Euphorbia esula). Weed Technology 9(3): 599-609.

Everitt, J. H., D. E. Escobar, M. A. Alaniz, M. R. Davis, and J. V. Richerdson. 1996. Using spatial information technology to map Chinese tamarisk (Tamarix Chinesis) infestations. Weed Science 44(1): 194-201.

Guyot, G. 1990. Optical properties of vegetation canopies. In Application of Remote Sensing in Agriculture, 19-43. M. D. Dteven and J. A. Clark, eds. London, U.K.: Butterworths.

Hanson, L. D., P. C. Robert, and M. Bauer. 1995. Mapping wild oat infestations using digital imagery for site-specific management for agricultural systems. ASA Misc. Publ. Madison, Wisc.: ASA, CSSA, and SSSA.

Hatfield, J. L., and P. J. Pinter, Jr. 1993. Remote sensing for crop protection. Crop Protection 12(8): 403-413.

Inoue, Y., S. Morinaga, and A. Tomita. 2000. A blimp-based remote sensing system for low-altitude monitoring of plant variables: A preliminary experiment for agriculture and ecological applications. International J. Remote Sensing 21(2): 379-385.

Jackson, R. D., and A. R. Huete. 1991. Interpreting vegetation indices. Prevent. Vet. Med. 11(3-4): 185-200.

Johnson, G. A., D. A. Mortensen, and C. A. Gotway. 1996. Spatial and temporal analysis of weed seedling population using geostatistics. Weed Science 44(3): 704-710.
Johnson, G. A., J. Cardina, and D. A. Mortensen. 1997. Site-specific weed management: Current and future direction. In The State of Site-Specific Management for Agriculture, 131-147. F. J. Pierce and E. J. Sadler, eds. Madison, Wisc.: ASA, CSSA, and SSSA.

Lamb, D. W. 1998. Opportunity for satellite and airborne remote sensing of weeds in Australian crops. In Precision Weed Management in Crops and Pasture: Proceedings of a Workshop, 48-54. R. W. Medd and J. E. Pratley, eds. 5-6 May. Adelaide, South Australia: CRC for Weed Management Systems.

Lamb, D. W., M. M. Weedon, and L. J. Rew. 1999. Evaluating the accuracy of mapping weeds in seeding crops using airborne digital imaging: Avena spp. in seeding triticale. Weed Research 39(6): 481-492.

Lass, L. W., and R. H. Callihan. 1997. The effect of phenological stage on detectability of yellow hawkweed (Hieracium pratense) and ox-eye daisy (Chrysanthemum leucanthemum) with remote multispectral digital imagery. Weed Technology 11(2): 248-256.

Lass, L. W., H. W. Carson, and R. H. Callihan. 1996. Detection of yellow starthistle (Centaurea solstitialis) and common St. John's wort (Hypericum perforatum) with multispectral digital imagery. Weed Technology 10(3): 466-474.

Medd, R. W., and J. E. Pratley. 1998. Preface in Precision Weed Management in Crops and Pasture: Proceedings of a Workshop. R. W. Medd and J. E. Pratley, eds. 5-6 May. Adelaide, South Australia: CRC for Weed Management Systems.

Menges, R. M., P. R. Nixon, and A. J. Richardson. 1985. Light reflectance and remote sensing of weeds in agronomic and horticultural crops. Weed Science 33(4): 569-581.

Moran, M. S., Y. Inoue, and E. M. Barnes. 1997. Opportunities and limitations for image-based remote sensing in precision crop management. Remote Sensing of Environment 61(3): 319-246.

Rew, L. J., and R. D. Cousens. 1998. What do we know about the spatial distribution of arable weeds? In Precision Weed Management in Crops and Pasture: Proceedings of a Workshop, 20-26. R. W. Medd and J. E. Pratley, eds. 5-6 May. Adelaide, South Australia: CRC for Weed Management Systems.

Zwiggelaar, R. 1998. A review of spectral properties of plants and their potential use for crop/weed discrimination in row-crops. Crop Protection 17(3): 189-206. 
